\title{
PELEPASAN HAK ATAS TANAH UNTUK KEPENTINGAN PERUSAHAAN
} SWASTA

\author{
Urip Santoso \\ Fakultas Hukum \\ Universitas Airlangga
}

\begin{abstract}
Abstrak
Perolehan tanah oleh perusahaan swasta dapat ditempuh melalui pelepasan hak atas tanah. Pelepasan hak atas tanah dapat dilakukan setelah ada kesepakatan dalam musyawarah mengenai bentuk dan besarnya ganti rugi. Pelepasan hak atas tanah oleh pemegang haknya dibuat dengan akta Notaris. Dengan pelepasan hak atas tanah tidak berakibat hak atas tanah berpindah kepada perusahaan swasta, akan tetapi hak atas tanah menjadi hapus dan kembali menjadi tanah Negara.
\end{abstract}

Kata kunci : Pelepasan hak, hak atas tanah, perusahaan swasta

\begin{abstract}
Acquisition of land by a private company can be reached through the release of land rights. Disposal of land rights can be done after there is agreement in the deliberations about the form and amount of indemnification. Disposal of land rights by the right holder is made by notarial deed. With the release of land rights does not result in land rights was transferred to private companies, but the right to remove and return the land to be State land.
\end{abstract}

Keywords: Release of rights, land rights, private enterprise.

\section{PENDAHULUAN}

Kegiatan pembangunan tidak hanya menjadi tanggung jawab Pemerintah, akan tetapi juga dibutuhkan peran aktif dari berbagai pihak, yaitu perusahaan swasta maupun masyarakat. Pembangunan yang dilaksanakan tersebut tidak dapat dilepaskan dengan kebutuhan akan tanah sebagai wadah kegiatannya.

Perusahaan swasta sangat diharapkan peran aktifnya dalam melaksanakan pembangunan di segala bidang. Untuk merealisasikan pem- bangunan dibutuhkan tanah yang akan digunakan oleh perusahaan swasta untuk keperluan pembangunan perumahan, industri (pabrik), pertokoan, perdagangan, perkantoran, rumah sakit, tempat wisata, dan hotel. Tanah yang dibutuhkan oleh perusahaan swasta untuk keperluan pembangunan tertentu harus berpedoman pada Rencana Tata Ruang Wilayah (RTRW) Kabupaten/Kota yang telah ditetapkan dalam Peraturan Daerah Kabupaten/Kota.

Meningkatnya kegiatan pembangunan dewasa ini membawa 
konsekuensi makin banyak dibutuhkan tanah. Kebutuhan akan tanah untuk memenuhi kebutuhan perusahaan swasta dari tahun ke tahun makin meningkat. Namun demikian, untuk memenuhi kebutuhan pembangunan tersebut seringkali terbentur oleh terbatasnya persediaan tanah yang ada. Hal ini nantinya dapat menimbulkan permasalahan-permasalahan di bidang pertanahan, misalnya terjadi persaingan dalam mendapatkan sebidang tanah, harga tanah yang terus melambung tinggi, atau terjadi sengketa dalam mendapatkan tanah.

Faktor-faktor yang menyebabkan meningkatnya kebutuhan akan tanah, adalah: (a)Pertumbuhan penduduk. (b)Meningkatnya kebutuhan penduduk akan ruang sebagai akibat peningkatan kualitas hidup. (c)Meningkatnya fungsi kota terhadap daerah sekitarnya. (d)Terbatasnya persediaan tanah yang langsung dapat dikuasai atau dimanfaatkan. (e)Meningkatnya pembangunan (Rusmadi Murad, 1997, 8).

Tanah-tanah yang tersedia untuk memenuhi kebutuhan pembangunan oleh perusahaan swasta sangat kecil kemungkinannya menggunakan tanah yang dikuasai langsung oleh Negara. Tanah yang dibutuhkan oleh perusahaan swasta hampir semuanya merupakan tanah hak yang dimiliki atau dikuasai oleh perseorangan, perusahaan, atau
Pemerintah Daerah.

Setelah mendapatkan pandangan tanah yang akan dijadikan lokasi pembangunan. Perusahaan swasta berkewajiban memiliki Izin Lokasi. Izin Lokasi diajukan oleh perusahaan swasta kepada Bupati/Walikota melalui Kepala Kantor Pertanahan Kabupaten/Kota setempat. Surat Keputusan Izin Lokasi ditandatangani oleh Bupati/Walikota setempat.

Selanjutnya, perusahaan swasta bernegosiasi dengan pemilik tanah atau pemegang hak atas tanah untuk bermusyawarah dengan maksud menentukan cara perolehan tanahnya. Untuk memperoleh tanah yang dibutuhkan oleh perusahaan swasta dapat ditempuh dengan cara meminta persetujuan dari pemegang hak atas tanah. Secara teoritik, ada 2 (dua) cara yang dapat ditempuh oleh perusahaan swasta untuk memperoleh tanah hak, yaitu pemindahan hak atas tanah melalui jual beli, atau pelepasan hak atas tanah.

Kegiatan perolehan tanah oleh perusahaan swasta atas tanah hak dikenal dengan sebutan pengadaan tanah untuk kepentingan perusahaan swasta. Selain itu ada pengadaan tanah oleh instansi Pemerintah, yaitu pengadaan untuk bagi pelaksanaan pembangunan untuk kepentingan umum yang luas tanahnya lebih dari 1 (satu) hektar disebut 
pengadaan tanah untuk kepentingan umum, dan pengadaan tanah bagi pelaksanaan pembangunan untuk kepentingan umum yang luas tanahnya tidak lebih dari 1 (satu) hektar disebut pengadaan tanah berskala kecil.

Dari ketiga cara perolehan tanah oleh perusahaan swasta, yang dibahas dalam tulisan ini difokuskan pada perolehan tanah melalui pelepasan hak atas tanah oleh pemegang haknya dari aspek pejabat yang berwenang membuat akta pelepasan hak atas tanah dan akibat hukum dari pelepasan hak atas tanah.

Dari uraian latar belakang masalah di atas, maka permasalahan yang hendak dikaji dirumuskan: (a)Pejabat yang berwenang membuat akta pelepasan hak atas tanah. (b)Akibat hukum pelepasan hak atas tanah.

\section{Pejabat Yang Berwenang Membuat Akta Pelepasan Hak Atas Tanah}

Pejabat umum yang terkait dengan perbuatan hukum mengenai hak atas tanah dan hak milik atas satuan rumah susun adalah Pejabat Pembuat Akta Tanah (PPAT) dan Notaris. Pejabat Pembuat Akta Tanah (PPAT) dan Notaris berbeda pengaturannya.

Pada saat ini mengenai Pejabat Pembuat Akta Tanah (PPAT) diatur dalam Peraturan Pemerintah No. 37 Tahun 1998 tentang Peraturan Jabatan
Pejabat Pembuat Akta Tanah. Peraturan Pemerintah No. 37 Tahun 1998 dilaksanakan oleh Peraturan Menteri Negara Agraria/Kepala Badan Pertanahan Nasional (Permen Agraria/Kepala BPN) No. 4 Tahun 1999 tentang Ketentuan Pelaksanaan Peraturan Pemerintah Nomor 37 Tahun 1998 Tentang Peraturan Jabatan Pejabat Pembuat Akta Tanah.

Peraturan Pemerintah No. 37 Tahun 1998 merupakan pelaksanaan Pasal 7 Peraturan Pemerintah No. 24 Tahun 1997 tentang Pendaftaran Tanah. Pasal 7 menyatakan: (1)Pejabat Pembuat Akta Tanah sebagaimana dimaksud dalam Pasal 6 ayat (2) diangkat dan diberhentikan oleh Menteri. (2)Untuk desa-desa dalam wilayah yang terpencil Menteri dapat menunjuk Pejabat Pembuat Akta Tanah Sementara. (3)Peraturan jabatan Pejabat Pembuat Akta Tanah sebagaimana dimaksud pada ayat (1) diatur dengan Peraturan Pemerintah.

Menurut Pasal 1 angka 24 Peraturan Pemerintah No. 24 Tahun 1997, yang dimaksud Pejabat Pembuat Akta Tanah (PPAT) adalah pejabat umum yang diberi kewenangan untuk membuat akta-akta tanah tertentu. Pengertian yang lebih lengkap mengenai Pejabat Pembuat Akta Tanah (PPAT) dinyatakan dalam Pasal 1 angkal Peraturan Pemerintah No. 37 Tahun 
1998, yaitu pejabat umum yang diberi kewenangan untuk membuat akta otentik mengenai perbuatan hukum tertentu mengenai hak atas tanah atau hak milik atas satuan rumah susun.

Dalam Peraturan Pemerintah No. 37 Tahun 1998, PPAT dibedakan menjadi 3 (tiga) macam, yaitu: (1)Pejabat Pembuat Akta Tanah. Seseorang diangkat sebagai Pejabat Pembuat Akta Tanah sekaligus merangkap sebagai Notaris. (2)Pejabat Pembuat Akta Tanah Sementara. Pejabat Pembuat Akta Tanah Sementara disini adalah Camat dan Kepala Desa yang ditunjuk oleh Kepala Badan Pertanahan Nasional Republik Indonesia. (3)Pejabat Pembuat Akta Tanah Khusus. Yang ditunjuk sebagai Pejabat Pembuat Akta Tanah Khusus adalah pejabat pada Badan Pertanahan Nasional.

Peraturan Pemerintah No. 37 Tahun 1998 menetapkan syarat-syarat untuk dapat diangkat sebagai PPAT, yaitu: (a)Berkewarganegaraan Indonesia; (b)Berusia sekurang-kurangnya 30 tahun; (b)Berkelakuan baik yang dinyatakan dengan surat keterangan yang dibuat oleh instansi kepolisian setempat; (c)Belum pernah dihukum penjara karena melakukan kejahatan berdasarkan putusan pengadilan yang telah mempunyai kekuatan hukum tetap; (d)Sehat jasmani dan rokhani; (e)Lulus- an Program Pendidikan Spesialis Notariat atau Program Pendidikan Khusus Pejabat Pembuat Akta Tanah yang diselenggarakan oleh Lembaga Pendidikan Tinggi; (f)Lulus ujian yang diselenggarakan oleh Kantor Menteri Negara Agraria/Badan Pertanahan Nasional.

Tugas pokok PPAT disebutkan dalam Pasal 2 ayat (1) Peraturan Pemerintah No. 37 Tahun 1998, yaitu melaksanakan sebagian kegiatan pendaftaran tanah dengan membuat akta sebagai bukti telah dilakukannya perbuatan hukum tertentu mengenai hak atas tanah atau hak milik atas satuan rumah susun, yang akan dijadikan dasar bagi pendaftaran perubahan data pendaftaran tanah yang diakibatkan perbuatan hukum itu. Dalam pendaftaran tanah terdapat 2 (dua) macam kegiatan, yaitu: (1)Kegiatan pendaftaran tanah untuk pertama kali. Kegiatan pendaftaran tanah untuk pertama kali dilakukan melalui pendaftaran tanah secara sporadik dan pendaftaran tanah secara ssistematik. (2)Kegiatan pemeliharaan pendaftaran tanah. Kegiatan pemeliharaan data pendaftaran tanah terdiri atas pendaftaran peralihan dan pembebanan hak, dan pendaftaran perubahan data pendaftaran tanah.

Dari 2 (dua) kegiatan pendaftaran tanah tersebut di atas, kegiatan yang 
menjadi tugas pokok PPAT dalam pendaftaran tanah adalah kegiatan pemeliharaan data pendaftaran tanah.

Pasal 2 ayat (2) Peraturan Pemerintah No. 37 Tahun 1998 menetapkan bahwa perbuatan hukum mengenai hak atas tanah atau hak milik atas satuan rumah susun yang membutuhkan akta yang dibuat oleh PPAT, adalah: (a)Jual beli; (b)Tukar menukar; (c)Hibah; (d)Pemasukan ke dalam perusahaan (inbreng); (e)Pembagian hak bersama; (f)Pemberian Hak Guna Bangunan/Hak Pakai atas tanah Hak Milik; (g)Pemberian Hak Tanggungan; (h)Pemberian kuasa membebankan Hak Tanggungan.

Kewenangan PPAT ditetapkan dalam Pasal 3 ayat (1) Peraturan Pemerintah No. 37 Tahun 1998, yaitu membuat akta otentik mengenai semua perbuatan hukum sebagaimana dimaksud dalam Pasal 2 ayat (2) mengenai hak atas tanah dan hak milik atas satuan rumah susun yang terletak di dalam daerah kerjanya. Atas dasar perbuatan hukum mengenai hak atas tanah atau hak milik atas satuan rumah susun, maka ditentukan bermacam-macam akta yang kewenangan membuatnya diserahkan kepada PPAT, yaitu: (a)Akta jual beli; (b)Akta tukar menukar; (c)Akta hibah; (d)Akta pemasukan ke dalam perusahaan (inbreng); (e)Akta pembagian hak bersama; (f)Akta pemberian Hak Guna Bangunan/Hak Pakai atas tanah Hak Milik; (g)Akta pemberian Hak Tanggungan; (h)Akta pemberian kuasa membebankan Hak Tanggungan.

Pada saat ini mengenai Notaris diatur dalam Undang-undang No. 30 Tahun 2004 tentang Jabatan Notaris. Undang-undang No. 30 Tahun 2004 secara tegas mencabut dan menyatakan tidak berlaku: (a)Reglement op Het Notaris ambt in Indonesie (Stb. 1860 No. 3) sebagaimana telah diubah terakhir dalam Lembaran Negara Tahun 1945 Nomor 101; (b)Ordonnantie 16 September 1931 tentang Honorarium Notaris; (c)Undang-undang Nomor 33 Tahun 1954 tentang Wakil Notaris dan Wakil Notaris Sementara (Lembaran Negara Tahun 1954 Nomor 101, Tambahan Lembaran Negara Nomor 700); (d)Pasal 54 Undang-undang Nomor 8 Tahun 2004 tentang Perubahan Atas Undang-undang Nomo0r 2 Tahun 1986 tentang Peradilan Umum (Lembaran Negara Republik Indonesia Tahun 2004 Nomor 34, Tambahan Lembaran negara Republik Indonesia Nomor 4379); (e)Peraturan pemerintah Nomor 11 Tahun 1949 tentang Sumpah/Janji Jabatan Notaris.

Menurut Pasal 1 angka 1 Undang-undang No. 30 Tahun 2004, yang dimaksud dengan Notaris, adalah 
pejabat umum yang berwenang untuk membuat akta otentik dan kewenangan lainnya sebagaimana dimaksud dalam Undang-undang ini. Notaris adalah pejabat umum dan akta yang dibuatnya adalah akta otentik. Dalam Undangundang No. 30 Tahun 2004 tidak diberikan pengertian tentang pejabat umum dan akta otentik.

Menurut Boedi Harsono, pejabat umum adalah seorang yang diangkat oleh Pemerintah dengan tugas dan kewenangan memberikan pelayanan umum di bidang tertentu (Boedi Harsono, 2007, 11). Notaris diangkat dan diberhentikan oleh Pemerintah melalui Menteri Hukum dan Hak Asasi Manusia. Tugas dan kewenangannya ditetapkan dalam Undang-undang No. 30 Tahun 2004.

Akta yang dibuat oleh Notaris adalah akta otentik. Menurut Pasal 1868 BW, akta otentik adalah suatu akta yang di dalam bentuk yang ditentukan oleh Undang-undang, dibuat oleh dan dihadapan pegawai-pegawai umum yang berkuasa untuk itu di tempat dimana akta dibuatnya (R. Soebekti dan R. Tjitrosoedibjo, 1985, 419). Suatu akta dinyatakan sebagai akta otentik apabila memenuhi unsur-unsur yang bersifat kumulatif sebagaimana yang ditentukan oleh Pasal 1868 BW, yaitu: (1)Bentuk akta ditentukan oleh Undang-undang;
(2)Akta dibuat oleh dan dihadapan pegawai-pegawai umum yang berkuasa; (3)Akta itu dibuat di tempat dimana akta dibuatnya.

Menurut Irawan Soerodjo, ada 3 (tiga) unsur yang merupakan esensialia agar terpenuhi syarat formal bahwa suatu akta merupakan akta otentik, yaitu: (1)Di dalam bentuk yang ditentukan oleh Undang-undang; (2)Dibuat oleh atau dihadapan pejabat umum; (3)Akta itu dibuat oleh atau dihadapan pejabat umum yang berwenang untuk itu dan di tempat dimana akta itu dibuat (Irawan Soerodjo, 2003, 148).

Suatu akta dinyatakan sebagai akta otentik apabila memenuhi 3 (tiga) unsur, yaitu: (1)Bentuk akta ditetapkan oleh Undang-undang. (2)Akta dibuat oleh atau dihadapan pejabat umum. (3)Akta itu dibuat oleh pejabat umum yang mempunyai daerah (wilayah) kerja tertentu.

Pasal 3 Undang-undang No. 30 Tahun 2004 menetapkan syarat-syarat untuk dapat diangkat sebagai Notaris, yaitu: (a)Warga Negara Indonesia; (b)Bertaqwa kepada Tuhan Yang Maha Esa; (c)Berumur paling sedikit 27 (duapuluh tujuh) tahun; (d)Sehat jasmani dan rokhani; (e)Berijazah Sarjana Hukum dan lulusan jenjang strata dua kenotariatan; (f)Telah menjalani magang atau nyata-nyata telah bekerja sebagai 
karyawan Notaris dalam waktu 12 (dua belas) bulan berturut-turut pada Kantor Notaris atas prakarsa sendiri atau atas rekomendasi Organisasi Notaris setelah lulus strata dua kenotariatan; dan (g)Tidak berstatus sebagai pegawai negeri, pejabat negara, advokat, atau tidak sedang memangku jabatan lain yang oleh Undang-undang dilarang untuk dirangkap dengan jabatan Notaris.

Kewenangan Notaris ditetapkan dalam Pasal 15 Undang-undang No. 30 Tahun 2004, yaitu: (1)Notaris berwenang membuat akta otentik mengenai semua perbuatan, perjanjian, dan ketetapan yang diharuskan oleh peraturan perundang-undangan dan/atau yang dikehendaki oleh yang berkepentingan untuk dinyatakan dalam akta otentik, menjamin kepastian tanggal pembuatan akta, menyimpan akta, memberikan grosse, salinan dan kutipan akta, semuanya itu sepanjang pembuatan aktaakta itu tidak juga ditugaskan atau dikecualikan kepada pejabat lain atau orang lain yang ditetapkan oleh Undangundang. (2)Notaris berwenang pula: (a)mengesahkan tanda tangan dan menetapkan kepastian tanggal surat di bawah tangan dengan mendaftar dalam buku khusus; (b)membukukan suratsurat di bawah tangan dengan mendaftar dalam buku khusus; (c)membuat kopi dari asli surat-surat di bawah tangan berupa salinan yang memuat uraian sebagaimana ditulis dan digambarkan dalam surat yang bersangkutan; (d)melakukan pengesahan kecocokan fotokopi dengan surat aslinya; (e)memberikan penyuluhan hukum sehubungan dengan pembuatan akta; (f)membuat akta yang berkaitan dengan pertanahan; dan (g)membuat akta risalah lelang. (2)Selain kewenangan sebagaimana dimaksud pada ayat (1) dan ayat (2), Notaris mempunyai kewenangan lain yang diatur dalam peraturan perundang-undangan.

Dari 2 (dua) pejabat umum yang terkait dengan perbuatan hukum mengenai hak atas tanah yang telah diuraikan di atas dapat dijelaskan bahwa pejabat umum yang berwenang membuat akta pelepasan hak atas tanah adalah Notaris. PPAT tidak berwenang membuat akta pelepasan hak atas tanah disebabkan akta yang menjadi kewenangan PPAT secara tersurat sudah ditetapkan dalam Pasal 2 ayat (2) Peraturan Pemerintah No. 37 Tahun 1998, yaitu perbuatan hukum mengenai jual beli, tukar menukar, hibah, pemasukan ke dalam perusahaan (inbreng), pembagian hak bersamaa, pemberian Hak Guna Bangunan/Hak Pakai atas tanah Hak Milik, pemberian Hak Tanggungan, dan pemberian kuasa membebankan Hak Tanggungan. Notaris berwenang membuat akta 
pelepasan hak atas tanah berdasarkan Pasal 15 ayat (2) huruf f Undang-undang No. 30 Tahun 2004, yaitu Notaris berwenang membuat akta yang berkaitan dengan pertanahan.

\section{Akibat Hukum Pelepasan Hak Atas Tanah}

Perolehan tanah dalam pengadaan tanah untuk kepentingan perusahaan swasta dapat ditempuh dengan cara pemindahan hak atas tanah melalui jual beli, atau pelepasan hak atas tanah. Antara jual beli dengan pelepasan hak atas tanah mempunyai perbedaan syarat sah dan prosedurnya.

Jual beli hak atas tanah merupakan salah satu contoh peralihan hak atas tanah yang berbentuk dialihkan. Peralihan hak atas tanah dibagi menjadi 2 (dua), yaitu: (1)Beralih. Berpindahnya hak atas tanah dari pemegang haknya kepada pihak lain disebabkan pemegang haknya meninggal dunia. Peralihan hak atas tanah disini terjadi karena hukum, artinya dengan meninggalnya pemegang hak atas tanah, maka ahli warisnya memperoleh hak atas tanah tersebut. (2)Dialihkan. Berpindahnya hak atas tanah dari pemegang haknya kepada pihak lain disebabkan suatu perbuatan hukum yang sengaja dilakukan dengan tujuan agar pihak lain tersebut memperoleh haki atas tanah. Perbuatan hukum tersebut berupa jual beli, hibah, tukar menukar, pemasukan dalam modal perusahaan (inbreng), atau lelang.

Menurut Boedi Harsono, jual beli tanah adalah perbuatan hukum yang berupa penyerahan Hak Milik (penyerahan tanah untuk selama-lamanya) oleh penjual kepada pembeli, yang pada saat itu juga menyerahkan harganya kepada penjual (Boedi Harsono, 1971, 135). Boedi Harsono menyatakan bahwa obyek jual beli tanah adalah sebatas Hak Milik. Dalam hukum positif, hak atas tanah yang dapat diperjualbelikan adalah Hak Milik, Hak Guna Usaha, Hak Guna Bangunan, dan Hak Pakai. Jual beli hak atas tanah adalah suatu perbuatan hukum untuk memindahkan hak atas tanah dari pemegang haknya sebagai penjual kepada pihak lain sebagai pembeli dan pada saat itu pula diserahkan sejumlah uang sebagai harga dari pembeli kepada penjual.

Syarat sah pendaftaran jual beli hak atas tanah ke Kantor Pertanahan Kabupaten/Kota ada 2 (dua), yaitu: (1)Syarat materiil. Pihak penjual (pemegang hak atas tanah) berhak dan berwenang menjual hak atas tanahnya, sedangkan pihak pembeli harus memenuhi syarat sebagai subyek hak dari hak atas tanah yang menjadi obyek jual beli. Kalau obyek jual beli hak atas tanah adalah Hak Milik, maka penjual berhak 
dan berwenang menjual hak milik atas tanahnya dan pembeli harus memenuhi syarat sebagai subyek Hak Milik. (2)Syarat formal. Jual beli hak atas tanah harus dibuktikan dengan akta yang dibuat oleh PPAT. Ketentuan ditegaskan dalam Pasal 37 ayat (1) Peraturan Pemerintah No. 24 Tahun 1997 tentang Pendaftaran Tanah, yaitu: "Peralihan hak atas tanah dan hak milik atas satuan rumah susun melalui jual beli, tukar menukar, hibah, pemasukan dalam perusahaan dan perbuatan hukum pemindahan hak lainnya, kecuali pemindahan hak melalui lelang hanya dapat didaftarkan jika dibuktikan dengan akta yang dibuat oleh Pejabat Pembuat Akta Tanah yang berwenang menurut ketentuan peraturan perundangundangan yang berlaku".

Dengan telah dibuatnya akta jual beli hak atas tanah oleh PPAT, maka telah terjadi pemindahan hak atas tanah dari penjual kepada pembeli. Pemindahan hak atas tanah tersebut hanya diketahui oleh penjual dan pembeli. Agar masyarakat mengetahui bahwa telah terjadi jual beli, maka jual beli hak atas tanah tersebut wajib didaftarkan ke Kantor Pertanahan Kabupaten/Kota setempat. Pendaftaran pemindahan hak atas tanah tersebut dengan maksud untuk dilakukan perubahan nama pemegang hak atas tanah yang tercantum dalam sertipikat dari pemegang hak yang lama menjadi pemegang hak yang baru oleh Kepala Kantor Pertanahan Kabupaten/ Kota setempat.

Kalau perolehan hak atas tanah dalam pengadaan tanah oleh perusahaan swasta ditempuh dengan cara jual beli, maka perusahaan swasta berkedudukan sebagai pihak pembeli sedangkan pihak yang tanahnya diperlukan oleh perusahaan swasta berkedudukan sebagai penjual. Perusahaan swasta yang berbentuk Perseroan Terbatas (PT) bukan sebagai subyek Hak Milik, melainkan sebagai subyek Hak Guna Usaha, Hak Guna Bangunan, atau Hak Pakai.

Kalau obyek jual beli hak atas tanah berupa Hak Milik, maka perusahaan swasta tidak dapat membeli hak atas tanah tersebut disebabkan oleh terbentur oleh syarat materiil dalam jual beli hak atas tanah, yaitu perusahaan swasta tidak memenuhi syarat sebagai subyek Hak Milik. Kalau syarat materiil dalam jual beli hak atas tanah tidak dapat dipenuhi, maka syarat formalnya tidak akan terpenuhi, yaitu berdasarkan Pasal 39 ayat (1) huruf c Peraturan Pemerintah No. 24 Tahun 1997 PPAT menolak untuk membuat akta jika salah satu pihak yang akan melakukan perbuatan hukum atau salah satu saksi tidak berhak atau memenuhi syarat untuk bertindak 
demikian.

Kalau obyek jual beli hak atas tanah tersebut berupa Hak Guna Usaha atau Hak Guna Bangunan, maka perusahaan swasta dapat membeli hak atas tanah tersebut. Kalau obyek jual beli hak atas tanah berupa Hak Pakai yang bersifat publik yang dikuasai oleh instansi Pemerintah, maka perusahaan swasta tidak dapat membeli hak atas tanah tersebut disebabkan hak atas tanah ini tidak dapat dipindahtangankan. Kalau obyek jual beli hak atas tanah berupa Hak Pakai yang bersifat privat, maka perusahaan swasta dapat membeli hak atas tanah tersebut.

Cara lain perolehan hak atas tanah yang dapat ditempuh oleh perusahaan swasta adalah melalui pelepasan hak atas tanah oleh pemegang haknya. Menurut Pasal 1 angka 3 Keputusan Menteri Negara Agraria/Kepala Badan Pertanahan Nasional No. 21 Tahun 1994 tentang Tata Cara Perolehan Tanah Bagi Perusahaan Dalam Rangka Penanaman Modal jo Pasal 1 angka 6 Peraturan Presiden No. 36 Tahun 2005 tentang Pengadaan Tanah Bagi Pelaksanaan Pembangunan Untuk Kepentingan Umum, yang dimaksud pelepasan atau penyerahan hak atas tanah adalah kegiatan melepaskan hubungan hukum antara pemegang hak atas tanah dengan tanah yang dikuasainya dengan pemberi- an ganti kerugian atas dasar musyawarah. Menurut Achmad Rubaie, pelepasan atau penyerahan hak atas tanah dilakukan melalui musyawarah berdasarkan kesepakatan di antara kedua belah pihak, yaitu pihak pemilik tanah dan pihak yang membutuhkan tanah (Achmad Rubaie, 2007, 121).

Dengan pelepasan atau penyerahan hak atas tanah, maka terputus sudah hubungan hukum antara pemegang hak atas tanah dengan tanah yang dikuasainya. Terputusnya hubungan hukum antara pemegang hak atas tanah dengan hak atas tanah yang dikuasainya tersebut terjadi dengan pemberian ganti kerugian yang bentuk dan besarnya ditetapkan dalam musyawarah.

Dalam pelepasan atau penyerahan hak atas tanah terdapat unsur pemberian ganti kerugian. Ganti kerugian diberikan oleh pihak yang memerlukan tanah (perusahaan swasta) kepada pihak pemegang hak atas tanah. Bentuk dan besarnya ganti kerugian ditetapkan atas dasar kesepakatan dalam musyawarah antara pihak yang memerlukan tanah (perusahaan swasta) dengan pihak pemegang hak atas tanah. Ganti kerugian diberikan untuk: (a)hak atas tanah; (b)bangunan; (c)tanaman; (d)bendabenda lain yang berkaitan dengan tanah.

Bentuk ganti kerugian dalam pelepasan atau penyerahan hak atas 
tanah dapat berupa: (a)uang; dan/atau (b)tanah pengganti; dan/atau (c)pemukiman kembali.

Pelepasan atau penyerahan hak atas tanah dapat dilakukan apabila sudah tercapai kesepakatan dalam musyawarah antara perusahaan swasta dengan pemegang hak atas tanah mengenai bentuk dan besarnya ganti kerugian. Kalau sudah tercapai kesepakatan mengenai bentuk dan besarnya ganti kerugian, maka dibuatlah akta pelepasan hak atas tanah atau surat pernyataan pelepasan hak atas tanah. Seiring dengan penandatanganan akta pelepasan hak atas tanah atau surat pernyataan pelepasan hak atas tanah oleh pemegang hak atas tanah, maka perusahaan swasta menyerahkan ganti kerugian secara langsung kepada pemegang hak atas tanah.

Pelepasan atau penyerahan hak atas tanah oleh pemegang haknya dibuat semata-mata untuk kepentingan perusahaan swasta. Pemegang hak atas tanah berkedudukan sebagai pihak yang melepaskan hak atas tanah, sedangkan perusahaan swasta berkedudukan sebagai pihak yang menerima pelepasan hak atas tanah.

Menurut Arie S Hutagalung, acara pelepasan hak ini ditempuh jika pihak yang bermaksud memperoleh dan menguasai tanah yang berstatus Hak
Milik atau eks Hak Milik Adat, namun tidak memenuhi syarat sebagai subyek pemegang hak atas tanah tersebut melalui pemindahan/peralihan hak secara langsung (Arie S Hutagalung, 2005, 179). Pelepasan hak atas tanah oleh pemegang haknya ditempuh oleh perusahaan swasta disebabkan perusahaan swasta tidak dapat memperoleh tanah yang berstatus Hak Milik melalui cara jual beli hak atas tanah. Perusahaan swasta tidak memenuhi syarat sebagai subyek Hak Milik, sehingga untuk memperoleh tanah yang berstatus Hak Milik ditempuh melalui cara pelepasan hak atas tanah oleh pemegang haknya dengan pemebrian ganti kerugian.

Boedi Harsono menyatakan bahwa dengan pelepasan hak atas tanah tidak berarti hak atas tanah berpindah dari pemegang haknya kepada pihak lain yang memberikan ganti kerugian, melainkan hak atas tanah tersebut hapus dan kembali menjadi tanah Negara atau tanah yang dikuasai langsung oleh Negara. Pelepasan hak atas tanah merupakan salah satu faktor penyebab hapusnya hak atas tanah dan bukan pemindahan hak atas tanah (Boedi Harsono, 1990, 168). Dengan pelepasan hak atas tanah oleh pemegang haknya, hak atas tanah tidak berpindah kepada perusahaan swasta, melainkan hak atas tanah menjadi hapus dan tanahnya 
kembali menjadi tanah Negara atau tanah yang dikuasai langsung oleh Negara.

Dalam Undang-undang No. 5 Tahun 1960 tentang Peraturan Dasar Pokok-pokok Agraria atau Undangundang Pokok Agraria (UUPA) dan Peraturan Pemerintah No. 40 Tahun 1996 tentang Hak Guna Usaha, Hak Guna Bangunan, dan Hak Pakai Atas Tanah ditetapkan faktor-faktor penyebab hapusnya hak atas tanah dan tanahnya kembali menjadi tanah Negara, yaitu: (a)Hak atas tanah dicabut untuk kepentingan umum. (b)Hak atas tanah diserahkan atau dilepaskan secara sukarela. (c)Hak atas tanah diterlantarkan. (d)Pemegang hak atas tanah tidak memenuhi syarat sebagai subyek hak atas tanah. (e)Hak Guna Usaha, Hak Guna Bangunan, atau Hak Pakai yang berakhir jangka waktunya dan tidak diperpanjang oleh pemegang haknya. (f)Hak Guna Usaha, Hak Guna Bangunan, atau Hak Pakai tidak diperbaharui haknya oleh pemegang haknya.

Ketentuan dalam Hukum Positif yang menunjukkan bahwa pelepasan hak atas tanah merupakan hapusnya hak atas tanah dan tanahnya kembali menjadi tanah Negara, yaitu: (a)Pasal 27 huruf a angka 2 UUPA. Hak Milik hapus bila tanahnya jatuh kepada Negara karena penyerahan secara sukarela oleh pemiliknya. (b)Pasal 34 huruf c UUPA. Hak Guna Usaha hapus karena dilepaskan oleh pemegang haknya sebelum jangka waktunya berakhir. (c)Pasal 40 huruf c UUPA. (d)Hak Guna Bangunan hapus karena dilepaskan oleh pemegang haknya sebelum jangka waktunya berakhir. (e)Pasal 17 ayat (1) dan ayat (2) Peraturan Pemerintah No. 40 Tahun 1996. (f)Hak Guna Usaha hapus karena dilepaskan secara sukarela oleh pemegang haknya sebelum jangka waktunya berakhir. (g)Pasal 35 ayat (1) dan Pasal 36 ayat (1) Peraturan Pemerintah No. 40 Tahun 1996. Hak Guna Bangunan atas tanah Negara hapus karena dilepaskan secara sukarela oleh pemegang haknya sebelum jangka waktunya berakhir. (h)Pasal 55 ayat (1) dan Pasal 56 ayat (1) Peraturan Pemerintah No. 40 Tahun 1996. Hak Pakai atas tanah Negara hapus karena dilepaskan secara sukarela oleh pemegang haknya sebelum jangka waktunya berakhir.

Ketentuan-ketentuan yang dimuat dalam akta pelepasan hak atas tanah yang dibuat oleh Notaris, yaitu: (a)Judul akta pelepasan hak atas tanah. (b)Nomor akta pelepasan hak atas tanah.(c)Saat dilakukan pelepasan hak atas tanah (hari, tanggal, bulan, dan tahun). (d)Nama Notaris yang membuat 
akta pelepasan hak atas tanah. (e)Pihak yang melepaskan hak atas tanah, yaitu nama, tempat tanggal lahir, pekerjaan, alamat, nomor Kartu Tanda Penduduk. (f)Pihak yang menerima pelepasan hak atas tanah, yaitu nama, tempat tanggal lahir, pekerjaan, alamat, nomor Kartu Tanda Penduduk. Nama ini bertindak sebagai direktur dari perusahaan swasta. (g)Hak atas tanah yang dilepaskan oleh pemegang haknya, yaitu status hak atas tanah, tanda bukti hak atas tanah (bersertipikat atau belum bersertipikat), luas tanah (M2), letak tanah (Jalan, Kelurahan/Desa, Kecamatan, Kabupaten/Kota, Provinsi), dan batas-batas tanah yang dilepaskan (utara, selatan, timur, dan barat). (h)Besarnya ganti kerugian yang diserahkan oleh perusahaan swasta kepada pemegang hak atas tanah. (i)Akibat hukum pelepasan hak atas tanah adalah hak atas tanah menjadi tanah Negara dan selanjutnya dapat diberikan kepada perusahaan swasta yang memberi ganti kerugian. (j)Jaminan dari pihak yang melepaskan hak atas tanah, yaitu pihak yang melepaskan hak atas tanah adalah benarbenar pemilik atau pemegang hak atas tanah, tanah yang dilepaskan tidak sedang dalam kedaaan sengketa (gugatan), tidak sedang dalam jaminan kepada pihak lain, dan tidak sedang dalam sitaan pihak lain. (k)Pihak-pihak yang menandatangani akta pelepasan hak atas tanah, yaitu Notaris, pihak yang melepaskan hak atas tanah (pemilik atau pemegang hak atas tanah), pihak yang menerima pelepasan hak atas tanah (perusahaan swasta), 2 (dua) orang saksi.

Dengan dibuatnya akta pelepasan hak atas tanah, maka hak atas tanah menjadi hapus dan tanahnya kembali menjadi tanah Negara. Selanjutnya perusahaan swasta berkewajiban mengajukan permohonan pemberian hak atas tanah yang dilepaskan tersebut kepada Kepala Badan Pertanahan Nasional Republik Indonesia melalui Kepala Kantor Pertanahan Kabupaten/ Kota setempat.

\section{PENUTUP}

Berdasarkan uraian tersebut di atas, maka dapat disimpulkan hal-hal sebagai berikut: (a)Perolehan tanah dalam pengadaan tanah untuk kepentingan perusahaan swasta dapat ditempuh melalui pelepasan hak atas tanah oleh pemegang haknya. Pelepasan hak atas tanah sebagai perolehan tanah ini ditempuh disebabkan perusahaan swasta tidak dapat melakukan jual beli yang terbentur oleh tidak terpenuhinya syarat materiil dalam jual beli, yaitu tidak memenuhi syarat sebagai subyek dari hak atas tanah yang diperlukan oleh perusahaan swasta. (b)Notaris ber- 
wenang membuat akta pelepasan hak atas tanah berdasarkan ketentuan Pasal 15 ayat (2) huruf f Undang-undang No. 30 Tahun 2004 tentang Jabatan Notaris. Pejabat Pembuat Akta Tanah (PPAT) tidak berwenang membuat akta pelepasan hak atas tanah berdasarkan ketentuan Pasal 2 ayat (2) Peraturan Pemerintah No. 37 Tahun 1998 tentang Peraturan Jabatan Pejabat Pembuat Akta Tanah. (c)Dengan dibuatnya akta pelepasan hak atas tanah, maka hak atas tanah tidak berpindah dari pemegang haknya kepada pihak yang memberikan ganti kerugian (perusahaan swasta), melainkan hak atas tanah menjadi hapus dan hak atas tanahnya kembali menjadi tanah Negara.

\section{DAFTAR PUSTAKA}

Harsono, Boedi, (1971). Undangundang Pokok Agraria Sedjarah Penjusunan, Isi, dan Pelaksanaannya, Djambatan, Djakarta

(1990). "Aspek Yuridis Penyediaan Tanah", Majalah HUKUM dan PEMBANGUNAN, Nomor 2 Tahun XX, Fakultas Hukum Universitas Indonesia, Jakarta

\section{(2007). "PPAT}

Sejarah Tugas dan Kewenangannya", Majalah RENVOI, No. 8.44. IV, Jakarta
Pemikiran Seputar Masalah Hukum Tanah, Lembaga Pemberdayaan Hukum Indonesia, Jakarta

Murad, Rusmadi, (1997.). Administrasi Pertanahan Pelaksanaannya Dalam Praktek, Mandar Maju, Bandung

Rubaie, Achmad, (2007). Hukum Pengadaan Tanah Untuk Kepentingan Umum, Bayumedia, Malang

Soebekti dan R. Tjitrosoedibjo, (1985). Kitab Undang-undang Hukum Perdata Burgerlijk Wetboek, Pradnja Paramita, Jakarta

Soerodjo, Irawan, (2003). Kepastian Hukum Hak Atas Tanah di Indonesia, Arkola

Hutagalung, Arie S, (2005). Tebaran 